\title{
PHYSIOLOGICAL MODEL TO ESTIMATE THE MATURITY OF SUGARCANE
}

\author{
Maximiliano Salles Scarpari ${ }^{1 *}$; Edgar Gomes Ferreira de Beauclair² \\ ${ }^{1}$ IAC/APTA - Centro de Cana-de-açúcar - C.P. 206 - 14001-970 - Ribeirão Preto, SP - Brasil. \\ ${ }^{2}$ USP/ESALQ - Depto. de Produção Vegetal - C.P. 9 - 13418-900 - Piracicaba, SP - Brasil. \\ *Corresponding author <msscarpa@iac.sp.gov.br>
}

\begin{abstract}
Sugarcane (Saccharum spp.) grows in different weather and management conditions which directly affect crop maturation. These conditions lead to the necessity of quantifying crop response to different stimuli for planning purposes. Forecast models for the quality of raw material are important tools in sugarcane farming, especially the forecast curve of sucrose accumulation in shoots. The goal of these models is to supply yield estimates during the crop cycle, aiming to characterize alternatives and to increase the efficacy for management and strategic decisions. The objective of this project was to develop empiric models capable of obtaining estimates of total recoverable sugar (TRS), for the varieties RB72454, SP81-3250 and SP80-1842 during the crop cycle, using reference data as the production factors. Sugarcane harvest results obtained in Piracicaba, State of São Paulo, Brazil were analyzed using the following parameters: maturation, stand age, type of soil, variety, flowering and management for the crops in the years 1998/99, 1999/00, 2000/01, 2001/02 and 2002/03. Models developed for these years were used to estimate TRS from the 2003/04 cropping season. All the forecast models for ratoon crops were significant indicating that they are an excellent tool to optimize agricultural planning.
\end{abstract}

Key words: climatology, crop models, productivity, regression, sucrose

\section{MODELO FISIOLÓGICO PARAAESTIMATIVADAMATURAÇÃO EMCANA-DE-AÇÚCAR}

\begin{abstract}
RESUMO: A cultura da cana-de-açúcar (Saccharum spp.) é submetida a diferentes condições ambientais e de manejo durante o seu desenvolvimento, o que afeta diretamente a maturação. Assim, surge a necessidade de se quantificar as respostas da cultura aos diferentes estímulos para fins de planejamento. Modelos de previsão da qualidade da matéria-prima tornam-se ferramentas importantes na lavoura canavieira, em especial a previsão da curva de acúmulo de sacarose nos colmos, objetivando suprir estimativas de rendimento ao longo da safra, visando à caracterização das alternativas de manejo, aumentando a eficácia das decisões gerenciais e estratégicas. Desenvolveram-se modelos empíricos capazes de obter estimativas de ATR - Açúcar Total Recuperável nas variedades RB72454, SP81-3250 e SP80-1842 ao longo da safra, utilizando dados referentes aos fatores de produção. Foram analisados os resultados de colheita realizados no município de Piracicaba - SP, dos anos safras 1998/99, 1999/00, 2000/01, 2001/02 e 2002/03 considerando a maturação, idade do canavial, solos, variedades, florescimento e manejo, utilizando-se de modelos estatísticos de estimativa da maturação para estimar a safra 2003/04. Todos os modelos de previsão para cana-soca mostraram-se significativos, sendo uma ótima ferramenta de auxílio para o planejamento agrícola otimizado.

Palavras-chave: climatologia, modelos de cultura, produtividade, regressão linear múltipla, sacarose
\end{abstract}

\section{INTRODUCTION}

Mathematical models are idealized representations of real world situations. The analyses of ecological systems begin with the assumption that the state of any system and at any moment can be quantitatively characterized and their changes can be described through mathematical equations (Wit \& Goudriaan, 1974).

For the sugarcane crop, empiric models are developed to simulate the partition of biomass into sucrose.
Stem growth and canopy development have priority use of the sucrose, only excess above what is needed for stem and canopy growth is stored. Climate is a major factor that influences sugarcane (Saccharum spp.) maturation and the increase in sucrose shoots. Climatic elements, such as precipitation and air temperature vary in different production areas, and models that do not address this effect in particular can at best represent a fraction of the total variation in maturity. Several authors have modeled the influence of 
evapotranspiration on crop productivity; however, the influence of water availability on maturity has not yet been sufficiently studied for the available varieties. A moderate drought and a cold period may induce sucrose accumulation in stems (Scarpari \& Beauclair, 2004).

The solar radiation converted into photoassimilate can be quantified as photosynthetic efficiency $\left(\mathrm{g} \mathrm{MJ}^{-1}\right)$, defined as the sucrose produced through the total photosynthesis $\left(\mathrm{g} \mathrm{m}^{-2} \mathrm{day}^{-1}\right)$ for the PAR - the intercepted fraction of Photosynthetically Active Radiation (MJ $\mathrm{m}^{-2}$ day $^{-1}$ ), excluding respiration losses (Singels et al., 2005). It is strongly related to temperature and can vary from $2.7 \mathrm{~g}$ of $\mathrm{CH}_{2} \mathrm{O} \mathrm{MJ}{ }^{-1}$ of PAR at $10^{\circ} \mathrm{C}$ to 8.2 $\mathrm{g} \mathrm{MJ}^{-1}$ at $20^{\circ} \mathrm{C}$ (Liu \& Bull, 2001). The CANEGRO model assumes a constant fraction of $5.68 \mathrm{~g} \mathrm{MJ}^{-1}$ (Singels \& Bezuidenhout, 2002).

Some adaptations have been made to the MST model - Matéria Seca Total (Barbieri, 1993). This model uses the relationship between the solar radiation intensity and photoassimilate production calculated through the data obtained by Bull (1969). The simulation of solar radiation capture is made using Beer's Law with an extinction coefficient ranging from 0.48 to 0.58 depending on the variety and the leaf area index - LAI increased as a function of thermal time up to 750 degrees, from there on it decreases (Scarpari, 2007). The correction of photoassimilate production is based on a function of LAI measured values adjusted by a non-linear function (Scarpari, 2007), air temperature on clear and cloudy days (Bull, 1967), stand age (Hartt \& Burr, 1967), growth respiration (Machado, 1981) and maintenance (Medina et al., 1970), soil water storage (Delgado Rojas, 1998) and flowering (Pereira et al., 1986).

The objective of this study was to develop empirical models of maturation for RB72454, SP813250 and SP80-1842 varieties using the MST model structure (Barbieri, 1993). The amount of photoassimilate was obtained using the methodology of negative degree-days (Scarpari \& Beauclair, 2004) and soil water storage (Thornthwaite \& Mather, 1955), to estimate Total Recoverable Sugar - TRS (CONSECANA, 2002) in kilograms of sucrose per ton of sugarcane, over the cropping season, using a multiple linear regression.

\section{MATERIALAND METHODS}

This project used the sugarcane harvest data obtained in Piracicaba, State of São Paulo, Brazil (22 ${ }^{\circ} 37^{\prime}$ $\mathrm{S}, 47^{\circ} 41^{\prime} \mathrm{W}$ ) which has a mean temperature of $21.5^{\circ} \mathrm{C}$, mean annual precipitation of $1,276 \mathrm{~mm}$, and mean altitude of $520 \mathrm{~m}$.
Data from 9,689 sugarcane samples taken from the 1998/99, 1999/00, 2000/01, 2001/02 and 2002/03 cropping seasons was analyzed in terms of quality (TRS), stand age, soil, variety, flowering and management, the same as proposed by Lawes \& Lawn (2005). Statistical models for estimating the quality of raw material were developed using the SAS "Statistical Analysis System” software from the 2003/04 crop season (SAS Institute, 1989). TRS of all samples was calculated as proposed by CONSECANA (2002) with the data from the five cropping seasons, analyzed after the models were constructed. The file for regression statistical procedure, classifies sequentially: the variety, the homogeneous areas - type of soil (A and $\mathrm{B}$ - higher environment related to the water soil availability, C and D - medium environment and E - lower environment (Prado et al., 2002), the stand age, and the date of harvest in the months of April, May and June; July, August and September; October, November and December.

The methodologies for calculating the negative degree-days were proposed by Scarpari \& Beauclair (2004) which corresponds to the area comprised between the base temperature, below which development is considered null, and the daily minimum temperature. Soil water storage was calculated from the water balance (Thornthwaite \& Mather, 1955) with modifications proposed by Barbieri et al. (1997).

According to Heemst (1986) and Barbieri (1993), the maximum production of photoassimilate is given by:

$C B_{\max }=n \cdot\left[F \cdot C B_{n}+(1-F) \cdot C B_{c}\right]$

where: $C B_{\max }=$ maximum production of photoassimilated $\left(\mathrm{kg}\right.$ hectare ${ }^{-1}$ month $\left.^{-1}\right), n=$ number of days, $F=$ fraction of days that were cloudy, (1-F) $=$ fraction of days that were clear, $C B_{n}=$ production of photoassimilate on a cloudy day ( $\mathrm{kg}^{n}$ hectare $^{-1}$ day), $C B_{c}=$ production of photoassimilate on a clear day ( $\mathrm{kg}$ hectare $^{-1}$ day),

$$
C B_{n}=10^{3} \cdot \frac{a}{b \cdot k} \cdot \ln \left(1+0.005 b \cdot \frac{Q_{o}}{N} / 1+0.005 b \cdot \frac{Q_{o}}{N} e^{-k(L A I)}\right) \cdot N
$$

$a=0.06193, b=0.261, k=$ extinction coefficient $=$ $0.48-0.58$ (Scarpari , 2007), $Q_{o}=$ radiation at the top of the atmosphere (cal $\mathrm{cm}^{-2}$ day), $N=$ day length, $L A I$ = leaf area index, $C B_{c}=$ production of photoassimilate on a clear day ( $\mathrm{kg}$ hectare ${ }^{-1}$ day).

$C B_{c}=10^{3} \cdot \frac{a}{b \cdot k} \cdot \ln \left(1+0.0133 b \cdot \frac{Q_{o}}{N} / 1+0.0133 b \cdot \frac{Q_{o}}{N} e^{-k(L A I)}\right) \cdot N$ 
The LAI correction was obtained from equation (5) because $C B_{\max }$ was determined only as a maximum LAI (Barbieri, 1993) and the LAI values adjusted with a non-linear function from Scarpari (2007).

$C_{(L A I)}=C B_{(L A I ~ 0-5)} / C B_{(L A I=5)}$

Considering the values of $C B_{(L A I)}$ for LAI ranging from 0 to 5 , the following function is obtained:

$C_{(L A I)}=\left[\ln \left(1.23309 / 1+0.23309 e^{\left.-{ }^{k(L A I)}\right)}\right)\right] .5 .05$

The equations for correction of the average air temperature, according to Bull (1967) and Barbieri (1993), are:

$C_{c}(t)=-0.774+0.0887 t\left({ }^{\circ} C\right)$

where: $C_{c}(\mathrm{t})=$ correction for clear days.

$C_{n}(t)=-0.636+0.0729 t\left({ }^{\circ} C\right)$

where: $C_{n}(\mathrm{t})=$ correction for cloudy days.

Considering the rates of photosynthesis presented by Hartt \& Burr (1967), the following stand age correction relating to the degree-days was used:

$C(i)=1.1166 e^{-0.0006} \sum G D ; R^{2}=0.9525$

where: $C(i)=$ correction for stand age, $\Sigma G D=$ degree-days with $T b=18^{\circ} \mathrm{C}$, for $\Sigma G D<140, C(i)=1$ and $\sum G D>1700, C(i)=0.4$.

According to the values presented by Machado (1981) it is necessary to assimilate $1.27 \mathrm{~g}$ of carbohydrate to produce $1 \mathrm{~g}$ of dry matter. The amount of correction for growth respiration is given by the following constant:

$C_{r c}=0.79$

where: $C_{r c}=$ correction for growth respiration.

The maintenance respiration correction is expressed by equation (10) in agreement with Barbieri (1993):

$C_{r m}=1-r_{\max } \cdot C_{r(t)} \cdot C_{r(i)}$

where: $C_{r m}=$ maintenance respiration correction, $r_{\max }$ $=$ maximum value of respiration $\left(30^{\circ} \mathrm{C}\right)=2.3 \mathrm{mg}$ of $\mathrm{CH}_{2} \mathrm{O}$ g of dry matter ${ }^{-1}, C_{r(t)}=$ maintenance respiration correction for temperature, $C_{r(i)}=$ maintenance respiration correction for stand age.

The value of $r_{\text {max }}$ was obtained from the results of Medina et al. (1970). Maintenance respiration correction for temperature $C_{r(t)}$ and stand age $C_{r(i)}$ were also obtained from the results of Medina et al. (1970) and presented by equations (11) and (12):

$C_{r(t)}=e^{-4.11+0.1383 t}\left({ }^{\circ} \mathrm{C}\right)$

For t $>30^{\circ} \mathrm{C}, C_{r(t)}=1$.
$C_{r(i)}=1.25\left(0.9994^{\Sigma G D}\right)$

For $\Sigma \mathrm{GD}<372, C_{r(i)}=1$.

Water storage correction was calculated using the methodology proposed by Jensen (1968) and the sensibility coefficient of water stress for each considered phase of growth (Delgado Rojas, 1998).

$Y a_{a}=Y m_{a} \cdot(E T r / E T m)_{1}^{0.491} \cdot(E T r / E T m)_{2}^{0.27} \cdot(E T r / E T m)_{3}^{0.08}$

where: ETr and ETm are real and maximum evapotranspirations, $Y a_{a}$ and $Y m_{a}$ are respectively, current and maximum productivities of sugar, 1, 2 and 3 are the emergence, tillering and maturity phases.

Flowering induction happens between February 25th and March 20th, at a latitude of $22^{\circ} \mathrm{S}$. Equation (14) indicates whether flowering induction occurred or not and considered the variety NA 56-79 as standard (Pereira et al., 1986).

$L=1.212-0.07508 X 1-0.01463 X 2$

where: $L>0$ non-flowering, $L<0$ flowering

flowering, $X 1=$ number of nights between February $25^{\text {th }}$ and March $20^{\text {th }}$ with a minimum temperature $\geq 18^{\circ} \mathrm{C}, X 2=$ number of days between February $25^{\text {th }}$ and March $20^{\text {th }}$ with a maximum temperature $\leq 31^{\circ} \mathrm{C}$.

If flowering occurs in the cropping season verified by the equation (14), equation (15) is applied. Sucrose loss due to flowering was calculated using the potential of the variety NA 56-79 with Iaia et al. (1985) data. However, differences exist between varieties in the intensity of flowering because each variety presents a certain behavior (Iaia et al., 1985). The beginning of the degree-days count is February $25^{\text {th }}$ and it ends at the time of harvesting.

$C_{f l}=-0.0002 \sum \mathrm{GD}+1.0827 \quad \mathrm{R}^{2}=0.9729$

where: $C_{f l}=$ flowering correction, $\Sigma G D=$ degree-days $\left(\mathrm{Tb}=18^{\circ} \mathrm{C}\right)$.

Photoassimilate partitioned to stems was calculated in agreement with Liu \& Bull (2001) as a function of air temperature.

The agroclimatic model used in this study was defined by a mathematical expression that relates the dependent variable TRS (Y) to the independent variables $\mathrm{X}_{\mathrm{i}}$ defined as negative degree-days, soil water storage and the amount of photoassimilated at intervals of 10 days preceding the harvest at each stand, in the following way:

$Y=a+b_{1} X_{1}+b_{2} X_{2}+b_{3} X_{3}+\ldots+b_{n} X_{n}$

The evaluation of the parameters $b 1, b 2, b 3, \ldots, b n$ in the adopted equation was performed using the "REG" procedure and the "STEPWISE" method, 
where the independent variables that take part in the model are selected through multiple linear regression. The "STEPWISE" method is used when the hypothesis is to predict or relate a sample to one or more independent variables (Robbins \& Daneman, 1999). Therefore, the relation between dependent and independent variables is explained, determining a logical relationship between them. In all procedures, the analysis of variance for the multiple linear regression was tested using the F test (Spiegel, 1972), up to the 10\% probability error level for rejecting the null hypothesis. This level is ordinarily used when dealing with random variables (Hoffman \& Vieira, 1977). The determination coefficient parameter $\left(\mathrm{R}^{2}\right)$, Willmott's index (1981) and the root-mean-square deviations were used as indicators of the model's precision.

\section{RESULTS AND DISCUSSION}

The maintenance respiration (corrected in function of temperature and stand age) also suffers the influence of other factors like $\mathrm{CO}_{2}$ and $\mathrm{O}_{2}$ concentration. In agreement with Loomis \& Amthor (1999), none of the methods has the ability to explain the interaction between respiration, photosynthesis and photorespiration. For growth respiration, Penning de Vries et al. (1974) found a solution for the problem creating a balance for used substrate. Thus, the correction of growth respiration was simplified. The MST model (Barbieri, 1993) considered a constant for growth respiration of $0.21 \mathrm{~g} \mathrm{~g}^{-1}$. Inman-Bamber (1991) used a constant of $0.242 \mathrm{~g} \mathrm{~g}^{-1}$ and Liu \& Bull (2001) of $0.33 \mathrm{~g} \mathrm{~g}^{-1}$ for new fibre.

The flowering model (equation 14) only indicated favorable environmental conditions in 1998. Therefore, the correction (equation 15) was applied to varieties that flower. The flowering correction reduced photoassimilate by $8 \%$. Berding \& Hurney (2005) penalize free flowering particularly in the first half of the harvest season, by a reductions of up to $10 \%$ of produced photoassimilate.

The independent variables consisted of values obtained up to 150 days before the harvest. Scarpari \& Beauclair (2004) associated the negative degree-days of five months before the harvest with the maturation stage. Glover (1971) related the sucrose content according to minimum temperatures three months before the harvest. The models are presented below.

Variety: RB72454, ratoon, homogeneous areas: C, previous harvest: July, August and September. TRS $=187.768254-0.376227 G D N 10-$ $0.107788 G D N 30-0.174377 G D N 40+0.133110 G D N 50$ - 0.267745 GDN80 - $0.559121 \mathrm{GDN} 90-$ 0.216612 GDN100 -0.094682GDN110 -

$\begin{array}{lllll}0.188560 G D N 120 & + & 0.115217 G D N 130 & - \\ 0.108953 G D N 140 & - & 0.244565 G D N 150 & + \\ 0.060919 A R M 10 & - & 0.146820 \text { ARM20 } & + \\ 0.084514 \text { ARM30 } & - & 0.049690 \text { ARM50 } & + \\ 0.096236 \text { ARM80 } & + & 0.353100 \text { ARM90 } & + \\ 0.183794 \text { ARM100 } & + & 0.075495 \text { ARM110 } & + \\ 0.098779 \text { ARM130 } & + & 0.199083 \text { ARM150 } & - \\ 0.032143 F O T O 10 & - & 0.023723 F O T O 30 & + \\ 0.031845 F O T O 50 & + & 0.011255 \text { FOTO60 } & + \\ 0.026781 F O T O 70 & - & 0.030164 \text { FOTO80 } & - \\ 0.045157 F O T O 90 & - & 0.034631 F O T O 110 & - \\ 0.023015 F O T O 120 & - & 0.007867 F O T O 130 & - \\ 0.006825 F O T O 140-0.008487 F O T O 150 ; & \end{array}$

$\mathrm{R}^{2}=0.2613 ; \mathrm{CV}=$ 7.94996; Root MSE = 11.10805; $\mathrm{n}=6563$

where: TRS $=$ Total Recoverable Sugar in kilograms of sucrose per ton of sugarcane, GDN10, 30, 40, 50, $80,90,100,110,120,130,140$ and $150=$ negative degree-days previous to $1-10,21-30,31-40,41-50,71-$ 80, 81-90, 91-100, 101 110, 111-120, 121-130, 131140 and 141-150 days of harvest respectively (in ${ }^{\circ} \mathrm{C}$ ), ARM10, 20, 30, 50, 80, 90, 100, 110, 130 and $150=$ soil water storage previous to $10,20,30,50,80,90$, $100,110,130$ and 150 days of harvest (in mm), FOTO10, 30, 50, 60, 70, 80, 90, 110, 120, 130, 140 and $150=$ amount of assimilate produced previous to $10,30,50,60,70,80,90,110,120,130,140$ and 150 days of harvest (in $\mathrm{kg}$ hectare $\mathrm{e}^{-1}$ ).

The independent variable with largest $\mathrm{R}^{2}$ was FOTO140 $\left(R^{2}=0.1005\right)$. This $R^{2}$ represents the variation of data that can explain with the selected variables in five croping seasons. This is acceptable when dealing with sugar mill data, but different from a controlled experiment for which some models are validated through $\mathrm{R}^{2}$. A positive signal of the parameter estimated for the negative degree-days indicated a beneficial effect of coldest temperatures on sucrose accumulation (Scarpari \& Beauclair, 2004). However, since the RB72454 variety has a late-season maturation (cutting is performed at the season end) suffering the effect of low night temperatures (below $10^{\circ} \mathrm{C}$ ) in June, July and August, where the signals of most negative degree-days parameters are negative (indicative of excessive cold) which is not beneficial for sucrose accumulation (Scarpari \& Beauclair, 2004) and for the next day photosynthesis rates (Grantz, 1989). The positive signal for soil water storage is indicative of moderate drought which benefits the maturation (Humbert, 1968).

A drought larger than $130 \mathrm{~mm}$ in the previous harvest, already affects the sucrose accumulation harming the maturation, giving a negative signal for soil water storage parameters (Scarpari \& Beauclair, 2004). 
Inman-Bamber (2004) mentions the drought value of $145 \mathrm{~mm}$ in relation to that. Higher values turn the carbon balance negative as the rate of respiration is larger than that of photosynthesis (Glover, 1974). Ashton (1956) verified that the photosynthetic rate begins to decrease when the soil water storage approaches an intermediate value between the field capacity and the permanent wilting point. Below this intermediate limit, the photosynthesis progressively decreases until it is near to null when close to the permanent wilting point.

When sugarcane biomass is reduced up to $10 \%$ (due to drought) the sucrose accumulation is usually increased or unaffected. If biomass is reduced beyond this point, reduction in the sucrose accumulation will occur (Robertson \& Donaldson, 1998). The low but significant $\mathrm{R}^{2}$ value $(0.2613)$ indicates that the model explains $26 \%$ of TRS variation as a function of the variations of the selected variables, with the remaining $74 \%$ being caused by factors not considered by the model. This can be explained by the time-space variability of the areas, besides factors not considered to be affected by the mineral nutrition, low-lying areas that for example tend to accumulate more water in the soil thus delaying maturity. Attack by pests and diseases could invert the sucrose, while specific differences in management and age may also influence maturity. The model presented acceptable coefficients of variation (CV) and root-mean-square deviations (Root MSE) of around 7.9 and 11.1, respectively.

Variety: SP80-1842, ratoon, homogeneous areas: E, previous harvest: July, August and September.

TRS $=149.215210+0.247882 G D N 10-$ 0.209214 GDN50 - 0.381975 GDN90 + $0.336413 G D N 100+0.490202 G D N 110-$ 0.121320 ARM30 - 0.321143 ARM60 + 0.232620 ARM90 +0.099074 ARM100 + 0.191990 ARM110 +0.117329 ARM120 $0.108551 \mathrm{ARM} 130-0.074258 \mathrm{FOTO} 20-$ $0.015472 \mathrm{FOTO} 110$ - 0.012933FOTO130;

$\mathrm{R}^{2}=0.4806 ; \mathrm{CV}=6.34835 ;$ Root MSE $=8.88239 ; \mathrm{n}$ $=1841$

where: TRS $=$ Total Recoverable Sugar in kilograms of sucrose per ton of sugarcane, GDN10, 50, 90, 100 and $110=$ negative degree-days previous to $1-10,41$ 50, 81-90, 91-100 and 101-110 days of harvest respectively (in ${ }^{\circ} \mathrm{C}$ ), ARM30, 60, 90, 100, 110, 120 and $130=$ soil water storage previous to $30,60,90,100$, 110, 120 and 130 days of harvest (in mm), FOTO20, 110 and $130=$ amount of assimilate produced previous to 20, 110 and 130 days of harvest (in kg hect$\left.\operatorname{are}^{-1}\right)$.

The independent variable with the highest $\mathrm{R}^{2}$ was FOTO130 $\left(\mathrm{R}^{2}=0.2779\right)$. The coefficient of variation
(CV) and root-mean-square deviations (Root MSE) are acceptable at around 6.3 and 8.8, respectively.

Variety: SP81-3250, ratoon, homogeneous areas: D, previous harvest: July, August and September.

TRS $=144.194531+0.532570$ GDN60 0.684498 ARM130 +0.044752 FOTO30 0.073737FOTO50 + 0.021144FOTO90;

$\mathrm{R}^{2}=0.3287 ; \mathrm{CV}=6.24919 ;$ Root MSE = 8.5308; $\mathrm{n}$ $=507$

where: TRS $=$ Total Recoverable Sugar in kilograms of sucrose per ton of sugarcane, GDN60 = negative degree-days previous to 60 days of harvest (in ${ }^{\circ} \mathrm{C}$ ), ARM130 = soil water storage previous to 130 days of harvest (in mm), FOTO30, 50 and $90=$ amount of assimilate produced previous to 30, 50 and 90 days of harvest (in kg hectare ${ }^{-1}$ ).

The independent variable with the highest $\mathrm{R}^{2}$ was GDN60 $\left(\mathrm{R}^{2}=0.2244\right)$. The signal for variable GDN60 indicates the positive influence of low temperatures on the sucrose concentration. By contrast, the negative signal of ARM130 proves that the soil water storage holds back the maturation as found in Alexander (1973). Temperature which varies from 10 to $20^{\circ} \mathrm{C}$ acts positively on maturation, without any chilling damages. The variation coefficient (CV) and root-meansquare deviations (Root MSE) are low, around 6.2 and 8.5 respectively.

After the construction of the models the next step is their validation. For this the estimated values from certain environmental conditions were compared with the measured values. The validation was made in a new cropping season (2003/04), which had not participated in the construction of the model. Mitchell (1997) calls this validation empirical as it is just part of the validation process. However, it is of extreme importance as the estimated values will be used as measured values in optimized models. In spite of this, empirical models based on observed data and expressed in regression equations should only be validated in local studies. Lawes \& Lawn (2005) mention examples of empirical models that can be used for many purposes in the Australian sugar industry. Bezuidenhout \& Singels (2007) followed the same line of study in South Africa.

These kinds of analyses can solve several problems in the crop supply-chain, as an addition to the agronomic research and as a forecast model of sugarcane maturation using climatic parameters instead of only the average crop yields without considering the influence of weather (Scarpari \& Beauclair, 2004).

The model validation can be seen in Figures 1 to 3. The $\mathrm{R}^{2}$ shown in the illustrations (Figures 1 to 3 ) represents the adjustment of data for the model in the validation with the new cropping season (2003/04). All 


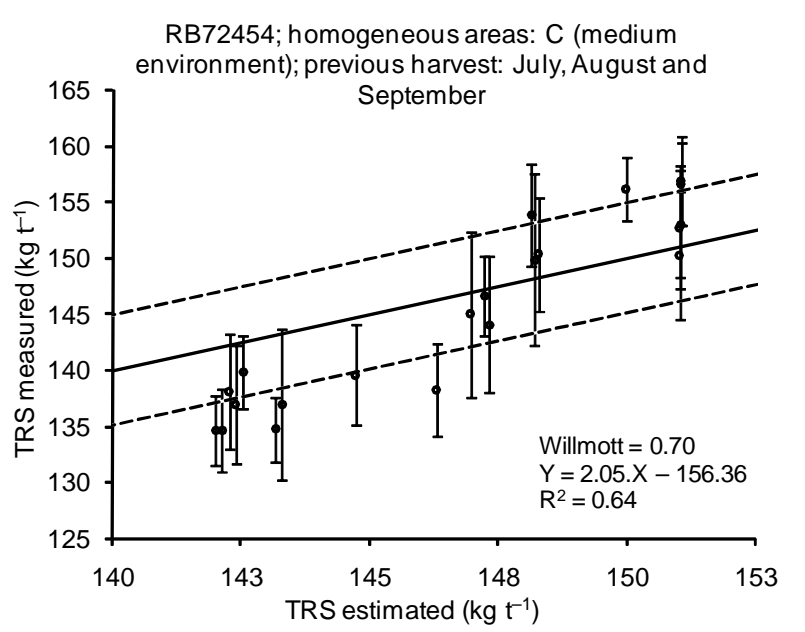

Figure 1 - Simulation between TRS measured in the samples and estimated by the model. Full line represents the line $1: 1$ and dashed lines the confidence limits $( \pm 95 \%)$. Bars indicate the standard deviation.

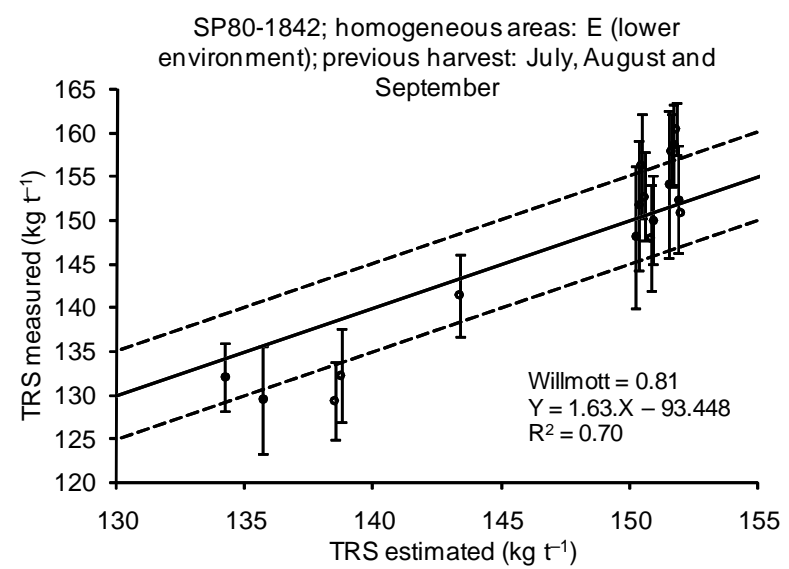

Figure 2 - Simulation between TRS measured in the samples and estimated by the model. Full line represents the line $1: 1$ and dashed lines the confidence limits $( \pm 95 \%)$. Bars indicate the standard deviation.

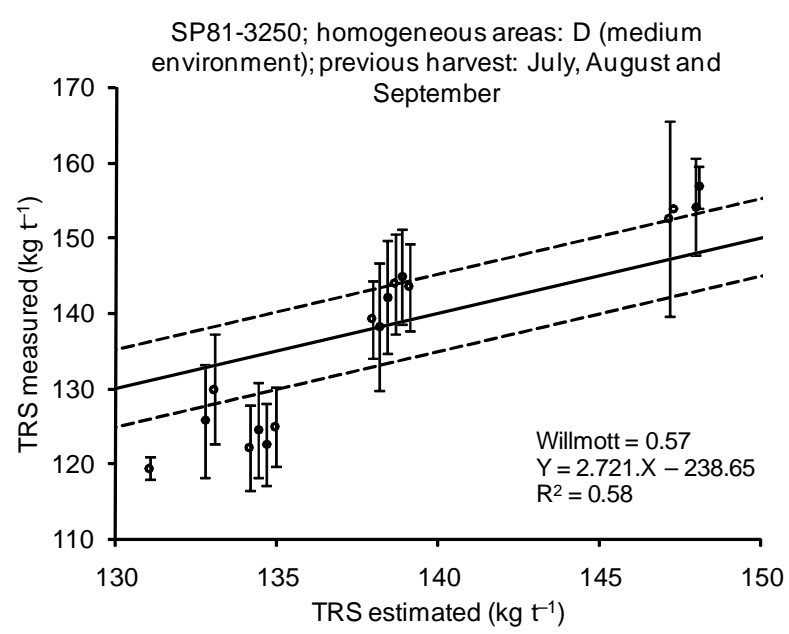

Figure 3 - Simulation between TRS measured in the samples and estimated by the model. Full line represents the line $1: 1$ and dashed lines the confidence limits $( \pm 95 \%)$. Bars indicate the standard deviation. maturation models appraised the TRS in an acceptable way for the 2003/04 cropping season, being an appropriate tool for use in optimized models. A small error came from SP81-3250 with $8.5 \mathrm{~kg}$ of sucrose $\mathrm{t}^{-1}$. O'Leary (2000) analyzing the APSIM - Sugarcane, CANEGRO and QCANE models presented values of Root MSE for sucrose in a stem of 4.93; 6.07 and $2.55 \mathrm{t}$ of sucrose hectare ${ }^{-1}$, respectively. The comparison of models is a difficult task, mainly when there is a shortage of information describing the mechanisms used in each model (Hansen \& Jones, 2000), but all models have a common objective, which is to simulate the sucrose accumulation in the shoot. The validation used weather events that had already occurred in the 2003/04 cropping season; however the model allows for the construction of several scenarios based on climatic forecast models at the beginning of the cropping season.

A greater number of observations (cropping seasons) and the repetition of these procedures will provide a better adaption to the simulation, but these results already allow for the use of this model to estimate the future of raw material quality, especially when creating more realistic scenarios. In relation to agronomic implications, TRS predictions are currently made for agronomical planning by using maturity curves obtained in assays of varieties cleared by research organizations or by consulting area histories, with a large amount of prediction errors, resulting from the huge knowledge gap with respect to the quantitative effects that factors exert on yields. When it comes to sugar export contracts and harvest planning, these estimates based solely on history, become extremely fragile (Everingham et al., 2007; Scarpari \& Beauclair, 2004; Scarpari et al., 2007).

\section{ACKNOWLEDGEMENTS}

This research was financed by FAPESP, 03/022324.

\section{REFERENCES}

ALEXANDER, A.G. Sugarcane physiology: a comprehensive study of the Saccharum source-to-sink system. Amsterdam: Elsevier, 1973. 752p.

ASHTON, F.M. Effects of a series of cycles of alternating low and high soil water contents on rate of apparent photosynthesis in sugar cane. Plant Physiology, v.31, p.266-274, 1956.

BARBIERI, V. Condicionamento climático da produtividade potencial da cana-de-açúcar (Saccharum spp.): um modelo matemático-fisiológico de estimativa. Piracicaba: USP/ESALQ, 1993. 142p. Tese (Doutorado).

BARBIERI, V.; TERUEL, D.A.; SILVA, J.G.; SANTOS, R.M.N. Balanço hídrico de Thornthwaite e Mather modificado para estimativa de deficiências nas culturas. In: CONGRESSO BRASILEIRO DE AGROMETEOROLOGIA, 10., Piracicaba, 1997. Anais. Piracicaba: SBAgro, 1997. p.587-589. 
BERDING, N.; HURNEY, A.P. Flowering and lodging, physiologicalbased traits affecting cane and sugar yield: what do we know of their control mechanisms and how do we manage them? Field Crops Research, v.92, p.261-275, 2005.

BEZUIDENHOUT, C.N.; SINGELS, A. Operational forecasting of South African sugarcane production. Part 1. System description. Agricultural Systems, v.92, p.23-38, 2007.

BULL, T.A. The taxonomic significance of quantitative morphological characters and physiological studies in Saccharum. In: CONGRESS OF THE INTERNATIONAL SOCIETY OF SUGARCANE TECHNOLOGISTS, 12., San Juan, 1965. Proceedings. Amsterdam: ISSCT, 1967. p.985-994.

BULL, T.A. Photosynthesis efficiencies and photorespiration in Calvin cycle and C4 dicarboxylic and plants. Crop Science, v.9, p.726-729, 1969.

CONSELHO DOS PRODUTORES DE CANA-DE-AÇÚCAR, AÇÚCAR E ÁLCOOL DO ESTADO DE SÃO PAULO CONSECANA. Manual de instruções. Piracicaba: CONSECANA, 2002. $117 p$.

DELGADO ROJAS, J.S. Modelo agrometeorológico para estimativa dos efeitos de deficiência hídrica na produtividade agro-industrial da cana-de-açúcar. Piracicaba: USP/ESALQ, 1998. 74p. Dissertação (Mestrado).

EVERINGHAM, Y.L.; INMAN-BAMBER, N.G., THORBURN, P.J.; McNEILL, T.J. A Bayesian modelling approach for long lead sugarcane yield forecasts. Australian Journal of Agricultural Research, v.58, p.87-94, 2007.

GLOVER, J. Changes in sucrose \% cane and yield of sucrose per unit area associated with cold, drought and ripening. In: SOUTH AFRICAN SUGARCANE TECHNOLOGISTS' ASSOCIATION, 45., Durban, 1971. Proceedings. Mount Edgecombe: SASTA, 1971. p.158-164.

GLOVER, J. The rate of apparent photosynthesis of whole sugarcane plants. Annals of Botany, v.38, p.909-920, 1974.

GRANTZ, D.A. Effect of cool temperatures on photosynthesis and stomatal conductance in field-grown sugarcane in Hawaii. Field Crops Research, v.22, p.143-155, 1989.

HANSEN, J.W.; JONES, J.W. Scaling-up crop models for climate variability applications. Agricultural Systems, v.65, p.4372, 2000

HARTT, C.E.; BURR, G.O. Factors affecting photosynthesis in sugarcane. In: INTERNATIONAL SOCIETY SUGARCANE TECHNOLOGISTS, 12., San Juan, 1965. Proceedings. Amsterdam: ISSCT, 1967. p.590-609.

HEEMST, H.D.J. van. Crop phenology and dry matter distribution. In: KEULEN, H. van; WOLF, J. (Ed.) Modelling of agricultural production: weather, soils and crops. Wageningen: PUDOC, 1986. p.27-40.

HOFFMAN, R.; VIEIRA, S. Análise de regressão: uma introdução a econometria. São Paulo: Hucitec, 1977. 379 p.

HUMBERT, R.P. The growing of sugarcane. Amsterdam: Elsevier, 1968. 779p.

IAIA, A.M.; LEE, T.S.G.; MATSUOKA, S.; PARAZZI, C., FERRARI, S.E.; BARBIERI, V. Efeito do florescimento no rendimento e na qualidade tecnológica da cana-de-açúcar. Brasil Açucareiro, v.103, p.18-25, 1985.

INMAN-BAMBER, N.G. A growth model for sugarcane based on a simple carbon balance and CERES-Maize water balance. South African Journal of Plant and Soil, v.8, p.93-99, 1991.

INMAN-BAMBER, N.G. Sugarcane water stress criteria for irrigation and drying off. Field Crops Research, v.89, p.107-122, 2004.

JENSEN, M.E. Water consumption by agricultural plants. In: KOZLOWZKI, T.T. (Ed.) Water deficits and plant growth. New York: Academic Press, 1968. p.1-22.

LAWES, R.A.; LAWN, R.J. Applications of industry information in sugarcane production systems. Field Crops Research, v.92, p.353-363, 2005.
LIU, D.L.; BULL, T.A. Simulation of biomass and sugar accumulation in sugarcane using a process-based model. Ecological Modelling, v.144, p.181-211, 2001.

LOOMIS, R.S.; AMTHOR, J.S. Yield potential, plant assimilatory capacity, and metabolic efficiencies. Crop Science, v.39, p.1584-1596, 1999.

MACHADO, E.C. Um modelo matemático-fisiológico para simular o acúmulo de matéria-seca na cultura da cana-de-açúcar (Saccharum spp.). Campinas: Unicamp, 1981. 115p. Dissertação (Mestrado).

MEDINA, E.; SAN JOSE, J.J.; SEQUERA, P.E. Análisis de la productividad en caña de azúcar. III. Respiración en la oscuridad de hojas y tallos de cinco variedades de caña de azúcar y pérdidas nocturnas de materia seca. Turrialba, v.20, p.302-306, 1970.

MITCHELL, P.L. Misuse of regression for empirical validation of models. Agricultural Systems, v.54, p.313-326, 1997.

O'LEARY, G.J. A review of three sugarcane simulation models with respect to their prediction of sucrose yield. Field Crops Research, v.68, p.97-111, 2000.

PENNING DE VRIES, F.W.T.; BRUNSTING, A.H.M.; LAAR, H.H. van. Products, requirements and efficiency of biosynthesis: a quantitative approach. Journal of Theoretical Biology, v.45, p.339-377, 1974.

PEREIRA, A.R.; BARBIERI, V.; MANIERO, M.A. Condicionamento climático da indução ao florescimento em cana-de-açúcar. STAB. Açúcar, Álcool e Subprodutos, v.4, p.56-59, 1986.

PRADO, H., LANDELL, M.G.A.; ROSSETTO, R. A importância do conhecimento pedológico nos ambientes de produção de canade-açúcar. In: REUNIÃO BRASILEIRA DE MANEJO E CONSERVAÇÃO DE SOLO E ÁGUA, 14., Cuiabá, 2002. Anais. Cuiabá: SBCS, 2002. CD-ROM.

ROBBINS, J.L.; DANEMAN, J.C. Parametric estimating \& the stepwise statistical technique. National Estimator, v.14, p.2434, 1999.

ROBERTSON, M.J.; DONALDSON, R.A. Changes in the components of cane and sucrose yield in response to drying-off of sugarcane before harvest. Field Crops Research, v.55, p.201-208, 1998.

SAS INSTITUTE. SAS language and procedures: usage, version 6. Cary: SAS Institute, 1989. 638p.

SCARPARI, M.S.; LANDELL, M.G.A.; BEAUCLAIR, E.G.F. Optimised agricultural planning of sugarcane using linear programming. In: CONGRESS OF THE INTERNATIONAL SOCIETY OF SUGARCANE TECHNOLOGISTS, 26., Durban, 2007. Proceedings. Durban: ISSCT, 2007. p.185-189.

SCARPARI, M.S. PREDPOL: um modelo de previsão da maturação da cana-de-açúcar visando planejamento otimizado. Piracicaba: USP/ESALQ, 2007. 120p. Tese (Doutorado).

SCARPARI, M.S.; BEAUCLAIR, E.G.F. Sugarcane maturity estimation through edaphic-climatic parameters. Scientia Agricola, v.61, p.486-491, 2004.

SINGELS, A.; BEZUIDENHOUT, C.N. A new method of simulating dry matter partitioning in the Canegro sugarcane model. Field Crops Research, v.78, p.151-164, 2002.

SINGELS, A.; DONALDSON, R.A.; SMIT, M.A. Improving biomass production and partitioning in sugarcane: theory and practice. Field Crops Research, v.92, p.291-303, 2005.

SPIEGEL, M.R. Estatística. São Paulo: McGraw-Hill, 1972. 580p. THORNTHWAITE, C.W.; MATHER, J.R. The water balance. Centertown: Drexel Institute of Technology, 1955. 104p.

WILlmotT, C.J. On the validation of model. Physical Geography, v.2, p.184-194, 1981.

WIT, C.T.; GOUDRIAAN, J. Simulation of ecological processes. Wageningen: The Netherlands Center for Agricultural Publishing and Documentation, 1974. 159p.

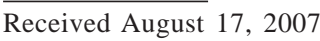

Accepted April 17, 2009 